\title{
Tacrine, a Drug with Therapeutic Potential for Dementia: Post-Mortem Biochemical Evidence
}

\author{
Paul T. Francis and David M. Bowen
}

\begin{abstract}
A review of biochemical findings is presented which support the idea that Alzheimer's disease represents a condition for which tetrahydroaminoacridine (tacrine) may have a beneficial effect. There is evidence that clinical and histopathologic hallmarks of the disease relate to cholinergic and serotonergic dysfunction, with less obvious abnormalities in other neurotransmitters (aspartate, dopamine, gamma-aminobutyrate, glutamate, noradrenaline and somatostatin). Clincially relevant concentrations of tacrine may ameliorate the above presynaptic deficits without producing harmful (neurotoxic) effects of aspartate and glutamate. The disease seems to be associated with an early and clinically relevant degeneration of some neurons with cortical perikarya that release these amino acid transmitters. Studies are now required on the effect of tacrine on postulated harmful peptide-bond hydrolase activity within and around such cells.

RÉSUMÉ: La tacrine, un médicament ayant un potentiel thérapeutique dans la démence: évidence biochimique post-mortem Nous présentons une revue des observations biochimiques supportant le concept que la maladie d'Alzheimer représente une pathologie dans laquelle la tetrahydroaminoacridine (tacrine) peut avoir un effet bénéfique. Il existe des données qui laissent croire que les stigmates cliniques et histopathologiques de la maladie sont en relation avec une dysfonction cholinergique et sérotoninergique, accompagnée d'anomalies plus discrètes des autres neurotransmetteurs (aspartate, dopamine, gamma-aminobutyrate, glutamate, noradrénaline et somatostatine). Des concentrations cliniquement appropriées des tacrine peuvent améliorer ces déficits présynaptiques sans produire les effets noscifs (neurotoxiques) de l'aspartate et du glutamate. La maladie semble être associée à une dégénérescence précoce et cliniquement significative de certains neurones, dont le corps neuronal est cortical, qui libèrent ces acides aminés agissant comme transmetteurs. L'effet de la tacrine sur l'activité de l'hydrolase, agissant au niveau des liaisons peptidiques et qu'on postule être néfaste dans et autour des cellules, doit maintenant être étudiée.
\end{abstract}

Can. J. Neurol. Sci. 1989; 16: 504-510

Recent datal (also unpublished observations) indicate that clinically relevant concentrations of 1,2,3,4-tetrahydro-9aminoacridine (tacrine) are unlikely to produce harmful (neurotoxic $^{2}$ ) effects of the excitatory amino acids (EAA, aspartate and glutamate). Such systemic doses, however, influence brain concentrations of other transmitters affected in Alzheimer's disease (AD). Data indicate that, at low concentrations, tacrine modulates monoaminergic transmission and inhibits acetylcholinesterase. ${ }^{3,4}$ It seems likely, therefore, that any effect of tacrine in $\mathrm{AD}$ depends, at least in part, upon its action on components of cholinergic and monoaminergic systems. We present here a review of postmortem biochemical findings which support the idea that $\mathrm{AD}$ represents a condition for which tacrine may have a beneficial effect.

\section{Problems Associated with Postmortem Neurochemical STUdies}

The prospect of obtaining meaningful data from diseased postmortem brain may be questioned as parameters under scrutiny may be influenced by factors such as patient age, sex, drug history, immediate pre-mortem status (sudden death or prolonged coma) and postmortem delay. Interpretation of postmortem data therefore requires fastidious consideration of these factors in order to separate changes that are due to the brain disease from those that occur as a result of epiphenomena. ${ }^{5-9}$

Tissue atrophy is another factor which may confound interpretation of data. This is because the practice of reporting results relative to unit mass (e.g. per $\mathrm{mg}$ of protein) does not make allowance for any reduction in volume of brain structure.

From the Department of Neurochemistry, Institute of Neurology, The National Hospital for Nervous Diseases (Queen Square), University of London, GB

Reprint requests to: Dr. P.T. Francis, Institute of Neurology, 1 Wakefield Street, London WCIN IPJ, UK 
Shrinkage or loss of some structures, but not others, may lead to the reporting of an increase in the markers of the unaffected structures, and, perhaps more importantly, an apparently small decrease in markers of the affected structures. For example, if a $35 \%$ reduction occurred of a structure constituting two-thirds of tissue volume, the reported loss of a biochemical marker (absent from unaffected structures) would be just $15 \%$. Thus, loss of a biochemical marker may be considerably underestimated, should the structure to which it relates represent a large proportion of tissue volume, such as pyramidal neurons within the cerebral cortex. Transmitter glutamate, probably associated with these pyramidal neurons of the cerebral cortex, may account for only $10-30 \%$ of tissue glutamate ${ }^{9,10}$ so even major losses of this structure would be difficult to detect from the glutamate content. Should losses occur equally in all cellular components (e.g. of pyramidal neurons and associated structures organized in columns), there would be no reported change in biochemical measures, even in severely atrophied tissue. Only a few studies have attempted to make allowance for this factor, by expressing results per entire brain region. ${ }^{11-13}$ Thus, although a hypertensive-agent related enzyme (angiotensin-converting enzyme) may be increased in $\mathrm{AD}, 14,15$ the change in mixed senile and vascular dementia is more obvious when allowance is made for atrophy. ${ }^{12}$ Likewise, the extent of loss in AD of serotonin (5HT) from the frontal lobe is only evident with such correction. ${ }^{13}$

It is not possible to distinguish reliably whether a reduced concentration of a marker is due to loss of the neurons which normally possess it, or to an alteration in the rate of its turnover, which may be a secondary phenomenon. Sodium-dependent uptake and calcium-dependent release of transmitter (depolarization evoked) provide important markers for the study of brains from experimental animals. However, because both of these processses require the maintenance of membrane potentials, they cannot be examined postmortem unless tissue is obtained shortly after death and assayed immediately9,16; tissue frozen in isotonic medium has also been used. ${ }^{17}$ Postmortem changes also influence the activity of specific marker enzymes such as dopamine-beta-hydroxylase and tryptophan hydroxylase. Finally, it is difficult to identify changes occurring early in $A D$ by examination of tissue obtained postmortem, where the disease has usually run its full course. ${ }^{18}$

\section{Neocortical Neurons}

\section{Excitatory amino acids (pyramidal neurons)}

Pyramidal cells are the largest and most abundant neuron type in the cerebral cortex. Recent quantitative morphological data on the distribution of plaques and tangles suggest that $A D$ may result at least, in part, from a loss of structural and functional integrity of pyramidal neurons forming corticocortical association projection fibres.9,19

The integrity of pyramidal neurons has been difficult to assess biochemically because of the ubiquitous distribution and many functions of EAA's. However, postmortem studies of both the uptake and binding of radiolabelled D-aspartic acid suggest that loss of some terminals of EAAergic neurons occurs, though the magnitude and distribution of such change, the extent of influence of artefact and epiphenomena and the location of the cell bodies is not yet clear. $9,11,20-25$

\section{Gamma-aminobutyric acid (GABA)}

Immunohistochemical studies have indicated that the majority of non-pyramidal interneurons in the cortex stain with antisera against GABA or its biosynthetic enzyme glutamic acid decarboxylase (GAD). Thus, GABA constitutes a major inhibitory transmitter system in the cortex, accounting for as many as 30 per cent of all cortical neurons. ${ }^{26}$ Large reductions in cortical GAD activity in AD were originally published alongside some of the first reports of diminished choline acetyltransferase (ChAT) activity. However, detailed studies of brain tissue obtained from diagnostic craniotomies and the brains of experimental animals suggested that loss of GAD activity was attributable to the terminal hypoxia associated with protracted death. ${ }^{7}$ No change in GAD activity was found in a recent study where $A D$ and control subjects were carefully matched for agonal state. ${ }^{27}$ Surprisingly, concentrations of GABA in subcortical structures have not been shown to be similarly affected 5 although GABA concentrations in the parietal cortex are probably affected by agonal state. ${ }^{7}$ There is evidence of reduced GABA concentrations in the temporal, frontal, parietal and occipital lobes in AD. ${ }^{7}$ The reductions found in most studies are less substantial and widespread than those reported by Ellison and colleagues ${ }^{28}$ who assayed subjects of similar age but included only pathologically severe examples of the disease. Large and widespread reductions in uptake sites of GABAergic neurons have also been reported. ${ }^{29}$ However, since this was based upon active uptake determinations in tissue that had been frozen, thawed and subfractionated it is difficult to exclude the possibility that inappropriate preparations were produced in disease affected tissue. Indeed, Simpson and colleagues ${ }^{30}$ find preservation of this uptake site (assayed using a ligand binding technique) in all regions examined, except the temporal cortex.

\section{Neuropeptides}

These appear to be localized in one broad class of interneuron, forming approximately $5 \%$ to $10 \%$ of the total cortical cell population. Current information indicates that virtually all of these interneurons are GABAergic. 26.31 Neuropeptides have been demonstrated to be stable in postmortem tissue and so they have been extensively studied in AD. 32

Despite relatively high concentrations in cerebral cortex, cholecystokinin, vasoactive intestinal polypeptide and neuropeptide $Y$ are unaffected. This may be adduced as evidence of relative sparing of the neurons that contain these peptides. The normal concentrations of vasoactive intestinal peptide are of particular interest in view of the reported co-existence between this peptide and ChAT activity within a population of non-pyramidal bipolar neurons. Such co-existence is not found in ascending cholinergic projections so the sparing of the peptide in AD may also indicate a sparing of intrinsic cholinergic neurons. Galanin exists in human basal forebrain cholinergic neurons but its "overactivity" may accentuate cholinergic dysfunction. 33 The localization of corticotropin-releasing factor in the cerebral cortex is not clear but it has been reported reduced, 34,35 whereas galanin appears unaltered. ${ }^{36}$

Many studies have demonstrated reduced somatostatin-like immunoreactivity (SLIR). Changes have been found to be greater in studies where only subjects displaying severe histopathology were examined than in those where no such 
selection criteria were employed.7,37 A difference in selection criteria may also explain why Beal and colleagues 38 found reduced concentrations of neuropeptide $Y$ whereas other groups have reported no change. A proportion of SLIR neurons in human cerebral cortex also stain for neuropeptide $\mathrm{Y},{ }^{39}$ so it is difficult to reconcile loss of SLIR with the sparing of neuropeptide Y. Studies in biopsy specimens from AD patients have not revealed any significant abnormality in the content or release of SLIR. 37

\section{Corticopetal Neurons}

\section{Acetylcholine}

Evidence for presynaptic cholinergic dysfunction in the cerebral cortex in $\mathrm{AD}$ has been obtained in all postmortem studies that have measured ChAT activity, radiolabelled choline uptake ${ }^{40}$ or acetylcholine content and release. ${ }^{41,42}$ These data are supported by a myriad of histological studies that have reported loss of cholinergic perikarya from the medial forebrain nucleus basalis of Meynert. ${ }^{43}$ Reduced ChAT activity is also a feature of "senile dementia of the Lewy body type" 44 (E.K. Perry, personal communication).

\section{Serotonin}

Serotonergic neurons, like cholinergic cells, innervate large areas of cerebral cortex from discrete extra-cortical (raphe) nuclei. However, serotonergic activity has been less thoroughly investigated in $A D$, largely because of the difficulty of measuring the activity of tryptophan hydroxylase in postmortem brain. With the exception of studies of the 5-HT carrier,45-47 all estimates of serotonergic neurons in postmortem samples have relied upon determination of the concentrations of 5-HT and its major metabolite, 5-hydroxyindoleacetic acid (5-HIAA 27,47,48). The 5-HT content in the neocortex from AD subjects has in general been found to be reduced whereas 5-HIAA was unaltered except for two reports of a reduced content of this metabolite. ${ }^{2-}$ 7,49 This discrepancy may be related to postmortem delay which was shorter in the latter studies than in studies of large groups of samples. 48 There is some evidence from histopathologic measurements to indicate that intrinsic cortical change and serotonergic denervation are related since significant negative correlations were found between tangle counts and 5-HIAA content in both frontal and temporal cortex of AD subjects. ${ }^{48}$ Aggressive $A D$ patients have a particularly low fronto-cortical concentration of 5-HT, suggesting that treatment with serotonomimetic agents could reduce the need for hospitalization. ${ }^{13}$

\section{Catecholamines}

The study of catecholaminergic neurons has been hampered by the postmortem instability of the enzymes responsible for the synthesis of dopamine (DA) and noradrenaline (NA). Apart from two studies of dopamine-beta-hydroxylase activity postmortem, one indicating reduced activity and other finding no change, biochemical studies of the cerebral cortex have focussed upon the determination of the concentrations of DA and NA and their principal metabolites, homovanillic acid (HVA) and 3-methoxy-4-hydroxyphenylglycol (MHPG), respectively. The concentration of DA has consistently been found not to be reduced. $48 \mathrm{HVA}$ concentrations are reported reduced in some regions, but elevated in others. ${ }^{48}$ Reduced concentrations of NA have generally been reported 47,48 whereas concentrations of MHPG have been found to be reduced, unaltered or even elevated.27,48 This may be a reflection of the postmortem accumulation of MHPG, 8 which, together with the high turnover rate and low concentrations of catecholamines in the cortex, make questionable the validity of determination of tissue concentrations postmortem. Moreover, since oxygen is a cofactor of both tyrosine hydroxylase and dopamine-beta-hydroxylase, the terminal hypoxia usually associated with AD may also be partly responsible for some of the observed changes. Noradrenergic changes in the cortex may be associated with neuronal loss from the brain stem noradrenergic nucleus, the locus ceruleus. ${ }^{50}$

\section{Neurotransmitter Recognition Sites}

Ligand binding studies in AD have indicated that some neurotransmitter recognition sites are unaltered in the cerebral cortex, even with allowance for tissue atrophy. 14 This includes those for a catecholamine, opiates, GABA and acetylcholine (muscarinic type). Assay of muscarinic receptor subtypes ${ }^{51}$ show the high affinity pirenzapine binding site $\left(M_{1}\right.$ receptor), the major postsynaptic receptor, to be apparently preserved,52,53 although no allowance for any atrophy was made. These findings suggest that a suitable target for acetylcholine is available in the cortex of AD patients but successful therapy with a cholinomimetic would help prove that this receptor is functionally intact. ${ }^{44} \mathrm{M}_{2}$ muscarinic receptors and nicotinic receptor sites (both of which are present in smaller numbers and may be primarily presynaptic) are reduced in the disease. $42,52,53,55$ Further studies on the location and physiological role of these receptors are necessary to assess the significance of these losses. Another consistent abnormality is that of recognition sites for 5-HT. Binding of $\left[{ }^{3} \mathrm{H}\right] 5-\mathrm{HT}$ (to the $5-\mathrm{HT}_{1}$ site) has been shown to be significantly reduced in the areas of cortex examined. Lower binding of $\left[{ }^{3} \mathrm{H}\right]$ ketanserin (to the $5-\mathrm{HT}_{2}$ site) has also been described. ${ }^{11,56}$ The binding of $\left[{ }^{3} \mathrm{H}\right]$ lysergic acid diethylamide (to both $5-\mathrm{HT}_{1}$ and $5-\mathrm{HT}_{2}$ sites) is reported significantly reduced in most studies, including the only one to make allowance for tissue atrophy by examination of the entire temporal lobe. ${ }^{14.45} 5$ $\mathrm{HT}_{\mathrm{IA}}$ receptors are reduced in some areas. 57,58

Although altered populations of EAA recognition sites have been reported in the neostriatum and the hippocampus, the neocortex has shown few alterations. ${ }^{19}$ Lower glutamate binding in cortical layers 1 and 2 and reduced glycine modulation of the $\mathrm{N}$ methyl-D-aspartate (NMDA) receptor have been described ${ }^{19,59}$ (the reduced binding of $\left[{ }^{3} \mathrm{H}\right]-\mathrm{TCP}$ to poorly washed membranes ${ }^{25}$ may also reflect this latter change). Reduced binding of radiolabelled somatostatin ${ }^{60}$ and corticotropin-releasing factor ${ }^{35}$ have been reported in the cerebral cortex, together with loss of $\mathrm{DA} \mathrm{D}_{2}$ receptors from the neostriatum, with the latter possibly reflecting loss of aspartate-releasing corticofugal pyramidal neurons from this region. $8,61,62,63$

\section{DATA FROM BIOPSY SAMPLES}

Small amounts of AD brain tissue, removed for diagnostic purposes, ${ }^{64,65}$ have also been used for biochemical analyses, ${ }^{66}$ an approach pioneered by Korey and colleagues. ${ }^{67}$ The few samples offered to the authors (39, between 1976 and 1987) originated from 7 centers. The material has, however, contributed to knowledge of the biochemistry of AD. Firstly, it has 
helped to separate disease-related change from the artefact and the epiphenomena normally associated with postmortem tissue (e.g. problems associated with GAD activity measurements). Secondly, it has allowed firmer conclusions to be drawn about neuronal integrity by permitting assessment of a variety of biochemical markers for a single neuronal type (Table 1). Thirdly, it has provided some insight into the neuronal changes that occur early in the disease, and, together with postmortem data, changes that occur at a later stage (Table 2). Finally, biochemical measures assessed antemortem in this laboratory have the advantage that there has often been a fixed and short duration ( $<2$ weeks) between neuropsychological assessment and the removal of tissue ${ }^{64,65}$ Moreover, detailed clinicopathological assessments have been made, including a rating of the magnitude of dementia on the basis of the performance of patients on a number of tests that assessed the extent of the following clinical domains: memory, perceptuo-spatial abilities and language. The rating correlated with acetylcholine synthesis, ${ }^{65,73}$ but not with other corticopetal transmitters ${ }^{18}$ and GABA was apparently increased or unaltered. ${ }^{7}$ Loss of pyramidal neurons may be a critical change since atrophy-corrected counts of pyramidal cells in cortical layers III and V of the same subjects were found to correlate with the magnitude of dementia. ${ }^{65}$ The significant association between PET-determined $18 \mathrm{~F}$-deoxyglucose uptake and behaviour ${ }^{74,75}$ may also reflect a relationship between pyra- midal cell dysfunction and the clincial symptoms of AD.

The fact that the disease is associated with alterations in potential biochemical markers of glutamate-releasing corticocortical pyramidal neurons, (Table 2), and structural changes in the cerebral cortex are demonstrated by other techniques (above), indicates a role for these cells in pathogenesis. For example, the postmortem data indicating a relationship between tangle counts and the cortical concentration of 5-HIAA have been confirmed in antemortem tissue, suggesting a pathogenic link between cortical cell dysfunction and corticopetal fibers. ${ }^{70}$ Retrograde degeneration ${ }^{76}$ of corticopetal cholinergic fibers (also from the cholinergic septal-hippocampal pathway) may occur as a consequence of reduced output of neurotrophic factors by the cortex (e.g. nerve growth factor ${ }^{77,78}$ ). Hypotrophic activity is likely to be secondary to the insult that causes death of EAA-releasing (see text and the seminal study of Hyman and colleagues ${ }^{79}$ ) corticocortical, corticofugal and hippocampal pyramidal neurons and the accumulation within these cells of abnormal inclusions (tangles, possibly granulovacuolar degeneration and Hirano/Lewy body formation.) The insult to these neurons is ascribed here to a toxin/infectious agent 80,81 inducing alterations in energy metabolism ${ }^{9,82-84}$ leading to a reduced $\mathrm{pH}$ value within and around pyramidal cells and stabilization of neutral-pH labile peptide-bond hydrolases. ${ }^{85}$ Owing to the protracted course of the disease, only a small portion of the brain

Table 1: Summary of Neurotransmitter Measures Assessed Antemortem in Neocortex of Patients with Alzheimer's Disease

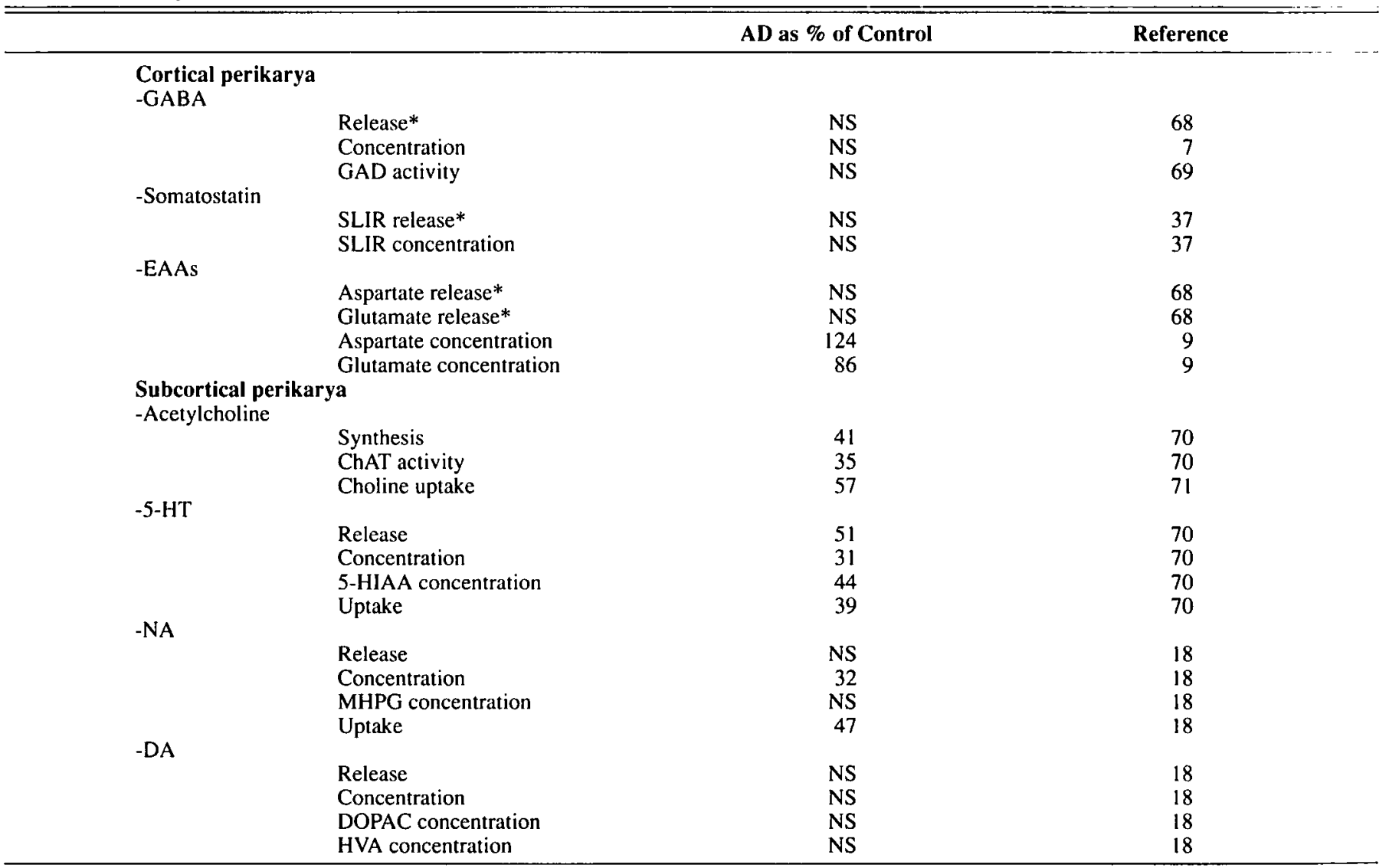

Percentages are given only for values that were significantly different from control; N.S. not significant; *static incubations without a reuptake inhibitor. 
Table 2: Excitatory Amino-Acid Neurotransmission in the Neocortex from Alzheimer Subjects Some 3 Years (neurosurgical samples) and 6-10 Years (autopsy material) After Onset

\begin{tabular}{lll}
\hline \hline & Early stage & Late Stage \\
\hline Glutamate, & & decreased* \\
- concentration & decreased & nd \\
- release & unchanged & unchanged \\
Aspartate, & & nd \\
- concentration & increased & decreased** \\
- release & unchanged & decreased* \\
Glutaminase activity & unchanged & decreased \\
D-aspartate uptake & nd & nd \\
D-aspartate "binding" & unchanged \\
NMDA-phencyclidine receptor & nd & unchanged \\
- cation channel & nd & \\
- glutamate site & decreased & decreased \\
- glycine site & unchanged \\
Kainate receptor binding & nd & unchanged \\
Quisqualate receptor binding & nd & unchanged \\
\hline
\end{tabular}

decrease/increase, identifies significant changes; nd, not determined; * specimens obtained within $3 \mathrm{~h}$ of death ** subject to unexplained variability or artefact $* * *$ hippocampus (see Table 1; also references $9,11,19,24,59,67,72$, and unpublished observations).

may show these changes at any given moment. ${ }^{86}$ It has been suggested that these changes begin in olfactory areas of the brain. The subsequent spread is via well defined neuronal pathways, initially involving cells of the limbic system but, as the disease progresses, those of the neocortex. ${ }^{57.76,87}$ Another mechanism proposed for increased protein degradation 88 is proteolytic activity associated with cholinesterase-rich pyramidal neurons. 89,91

It is well known that tacrine is an effective inhibitor of acetylcholinesterase and a preliminary study ${ }^{92}$ has tentatively confirmed the reported therapeutic efficacy in AD. ${ }^{3}$ Studies are now required on the effect of tacrine on the postulated harmful proteolytic activity within and around pyramidal cells, in particular in relation to the turnover of cell survival-related receptors $2,93,94$ as well as nerve growth factor. There is now some hope that disease progression ${ }^{95}$ can be slowed down by an inhibitor of peptide-bond hydrolases so it is particularly important to determine rate of decline in cognitive performance, 96 before inclusion in a clinical trial. Clearly, improved methods of early diagnosis are urgently required.

\section{ACKNOWLEDGEMENT}

Funded in part by Astra Alab.

\section{REFERENCES}

1. Steele JE, Palmer AM, Lowe SL, et al. The influence of tetrahydro9-aminoacridine on excitatory amino acid neurotransmission in vivo and in vitro. Br J Pharmacol 1989; 96: 3530.

2. Mattson MP. Neurotransmitters in the regulation of neuronal cytoarchitecture. Brain Res Rev 1988; 13: 179-212.

3. Summers WK, Majouski LV, Marsh GM, et al. Oral tetrahydroaminoacridine in long-term treatment of senile dementia, Alzheimer type. New Eng J Med 1986; 315: 1241-124.

4. Robinson TN, De Souza RJ, Cross AJ, et al. The mechanism of tetrahydroaminoacridine (THA)-evoked release of endogenous 5-hydroxytryptamine and dopamine from rat brain prisms. Brit $J$ Pharmacol (in press).

5. Spokes EGS. An analysis of factors influencing measurements of dopamine, noradrenaline, glutamate decarboxylase, and choline acetyltransferase in human postmortem brain. Brain 1979; 102: 333-346.

6. Cheetham SC, Crompton MR, Katona LE, et al. Brain $\mathrm{GABA}_{\mathrm{A}}$ /benzodiazepine binding sites and glutamic decarboxylase activity in depressed suicide victims. Brian Res 1988; 460: 114-123.

7. Lowe SL, Francis PT, Procter AW, et al. Gamma-aminobutyric acid concentration in brain tissue at two stages of Alzheimer's disease. Brain 1988; 111: 785-799.

8. Palmer AM, Lowe SL, Francis PT, et al. Are postmortem biochemical studies of human brain worthwhile? Biochem Soc Trans 1988; 16: 472-475.

9. Procter AW, Palmer AM, Francis PT, et al. Evidence of glutamatergic denervation and possible abnormal metabolism in Alzheimer's disease. J Neurochem 1988; 50: 790-802.

10. Nicholls DG, Sihara TS, Sanchez-Prieto J. Calcium-dependent and -independent release of glutamate from synaptosomes monitored by continuous fluorometry. J Neurochem 1987; 49: 50-57.

11. Procter AW, Lowe SL, Palmer AM, et al. Topographical distribution of neurochemical changes in Alzheimer's disease. J Neurol Sci 1988; 84: 125-140.

12. Bowen DM, Davison AN. Biochemical studies of nerve cells and energy metabolism in Alzheimer's disease. Brit Med Bull 1986; 42: $75-80$.

13. Palmer AM, Stratmann GC, Procter AW, et al. Possible neurotransmitter basis of behavioural changes in Alzheimer's disease. Ann Neurol 1988; 23: 616-620.

14. Bowen DM, White P, Spillane JA, et al. Accelerated aging or selective neuronal loss as an important cause of dementia? Lancet 1979; i: 11-14.

15. Arregui A, Perry EK, Rossor M, et al. Angiotensin converting enzyme in Alzheimer's disease: Increased activity in caudate nucleus and cortical areas. J Neurochem 1982; 38: 1490-1492.

16. Bowen DM, Sims NR, Lee KAD, et al. Acetylcholine synthesis and glucose oxidation are preserved in human brain obtained shortly after death. Neurosci Lett 1982; 31: 195-199.

17. Dodd PR, Hambley JW, Cowburn RF, et al. A comparison of methodologies for the study of functional transmitter neurochemistry in human brain. J Neurochem 1988; 50: 1333-1345.

18. Palmer AM, Francis PT, Bowen DM, et al. Catecholaminergic neurons assessed antemortem in Alzheimer's disease. Brain Res 1987; 414: 365-37.

19. Procter AW, Wong EHF, Stratmann GC, et al. Reduced glycine stimulation of $\left[{ }^{3} \mathrm{H}\right] \mathrm{MK} 801$ binding in Alzheimer's disease. J Neurochem 1989; 53: 698-704. 
20. Palmer AM, Procter AW, Stratmann GC, et al. Excitatory amino acid-releasing and cholinergic neurons in Alzheimer's disease. Neurosci Lett 1986; 66: 199-204.

21. Cross AJ, Slater P, Candy JM, et al. Glutamate deficits in Alzheimer's disease. J Neurol Neurosurg Psychiatry 1987; 50:357-358.

22. Hardy J, Cowburn R, Barton A, et al. Region-specific loss of glutamate innervation in Alzheimer's disease. Neurosci Lett 1987; 73: 77-80.

23. McGeer EG, Singh EA, McGeer PL. Sodium-dependent glutamate binding in senile dementia. Neurobiol Aging 1987; 8: 219-223.

24. Cowburn R, Hardy J, Roberts P, et al. Presynaptic glutamatergic function in Alzheimer's disease. Brain Res 1988; 452: 403-407.

25. Simpson MDC, Royston MC, Deakin JFW, et al. Regional changes in [ $\left.{ }^{3} \mathrm{H}\right] \mathrm{D}$-aspartate and $\left[{ }^{3} \mathrm{H}\right] \mathrm{TCP}$ binding sites in Alzheimer's disease brains. Brain Res 1988; 462: 76-82.

26. Jones EG. Neurotransmitters in the cerebral cortex. J Neurosurg 1986; 65: 135-153.

27. Reinikainen KJ, Paljarvi L, Huuskonen M, et al. A postmortem study of noradrenergic, serotonergic and GABAergic neurons in Alzheimer's disease. J Neurol Sci 1988; 84: 101-116.

28. Ellison DW, Beal MF, Mazurek MF, et al. A postmortem study of amino-acid neurotransmitters in Alzheimer's disease. Ann Neurol 1986; 20: 616-621.

29. Hardy J, Cowburn R, Barton A, et al. A disorder of cortical GABAergic innervation in Alzheimer's disease. Neurosci Lett 1987; 73: 192-196.

30. Simpson MDC, Cross AJ, Slater P, et al. Loss of cortical GABA uptake sites in Alzheimer's disease. J Neural Trans 1988; 71: 219-226.

31. Jones EG, Hendry SHC. Expression of neuronal diversity in the central nervous system $I n$ : Jones EG, ed. Molecular Biology of the Human Brain. New York: Alan R. Liss Inc, 1988: 3-11.

32. Beal MF, Martin JB. Neuropeptides in neurological disease. Ann Neurol 1986; 20: 547-565.

33. Chan-Palay V. Galanin hyperinnervates surviving neurons of the human basal nucleus of Meynert in dementia of Alzheimer's and Parkinson's disease: A hypothesis for the role of galanin in accentuating cholinergic dysfunction in dementia. J Comp Neurol 1988; 173: 543-557.

34. Bissettee G, Reynolds GP, Kilts CD, et al. Corticotropin-releasing factor-like immunoreactivity in senile dementia of the Alzheimer type. JAMA 1985; 254: 3067-3069.

35. De Souza EB, Whitehouse PJ, Kuhar MJ, et al. Reciprocal changes in corticotropin-releasing factor (CRF)-like immunoreactivity and CRF receptors in cerebral cortex of Alzheimer's disease. Nature 1986; 319: 593-545.

36. Beal MF, Clevens RA, Chattha GK, et al. Galanin-like immunoreactivity is unchanged in Alzheimer's disease and Parkinson's disease dementia cerebral cortex. J Neurochem 1988; 51: 19351941.

37. Francis PT, Bowen DM, Lowe SL, et al. Somatostatin content and release measured in cerebral biopsies from demented patients. J Neurol Sci 1987; 78: 1-16.

38. Beal MF, Mazurek MF, Geetinder KC, et al. Neuropeptide $Y$ immunoreactivity is reduced in cerebral cortex in Alzheimer's disease. Ann Neurol 1986; 20: 282-288.

39. Vincent SR, Johannson U, Hokfelt T. Neuropeptide coexistence in human neurons. Nature 1982; 298: 65-67.

40. Rylett RJ, Ball MJ, Colhoun EH. Evidence for high affinity choline transport in synaptosomes prepared from hippocampus of patients with Alzheimer's disease. Brain Res 1983; 289: 169 175 .

41. Richter JA, Perry EK, Tomlinson BE. Acetylcholine and choline levels in postmortem human tissue: Preliminary observations in Alzheimer's disease. Life Sci 1980; 26: 1683-1689.

42. Nordberg A, Adem A, Nilsson L, et al. Cholinergic deficits in CNS and peripheral non-neuronal tissue in Alzheimer's disease. In: Dowdall MJ, Hawthome JN, eds. Cellular and Molecular Basis of Cholinergic Function. Chichester: Ellis Horwood, 1987: 858868.

43. Arendt T, Bigl V. Alzheimer's plaques and cortical cholinergic innervation. Neurology 1986; 17: 277-279.
44. Perry RH, Irving D, Blessed G, et al. Clinically and neuropathologically distinct form of dementia in the elderly. Lancet 1989 ; i: 166 .

45. Bowen DM, Allen SJ, Benton JS, et al. Biochemical assessment of serotonergic and cholinergic dysfunction and cerebral atrophy in Alzheimer's disease. J Neurochem 1983; 41: 266-272.

46. Perry EK, Marshall EF, Blessed G. Decreased imipramine binding in the brains of patients with depression. Brit J Psychiat 1983 142: $188-192$

47. D'Amato RJ, Zweig RM, Whitehouse PJ, et al. Aminergic systems in Alzheimer's disease and Parkinson's disease. Ann Neurol 1987; 22: 229-236.

48. Palmer AM, Wilcock GK, Esiri MM. Monoaminergic innervation of the frontal and temporal lobes in Alzheimer's disease. Brain Res 1987; 401: 231-238.

49. Cross AJ, Crow TJ, Johnson JA, et al. Monoamine metabolism in senile dementia of Alzheimer type. J Neurol Sci 1983; 60: 383392.

50. Iversen LL, Rossor MW, Reynolds GP, et al. Loss of pigmented dopamine-B-hydroxylase positive cells from locus ceruleus in senile dementia of Alzheimer's type. Neurosci Lett 1984; 34 : 95 100.

51. Birdsall NJM, Hulme EC. Future directions. In: Heller-Brown J, ed. Muscarinic Receptors. New Jersey: Humana Press (in press).

52. Flynn DD, Mash DC. Characterization of $\left[{ }^{3} \mathrm{H}\right]$ nicotine binding in human cerebral cortex: Comparison between Alzheimer's disease and normal. J Neurochem 1986; 47: 1948-1954.

53. Smith CJ, Perry EK, Perry RH, et al. Muscarinic cholinergic receptor subtypes in hippocampus in human cognitive disorders. J Neurochem 1988; 50: 547-8546.

54. Young LT, Kish SJ, Li PP, et al. Decreased brain $\left[{ }^{3} \mathrm{H}\right]$-inositol 1,4,5-trisphosphate binding in Alzheimer's disease. Neurosci Lett 1988; 94: 198-202.

55. Whitehouse PJ, Marinu AM, Antuono PG, et al. Nicotine acetylcholine binding sites in Alzheimer's disease. Brain Res 1986; 371: 146-151.

56. Cross AJ, Crow TJ, Ferrier IN, et al. The selectivity of the reduction of serotonin $\mathrm{S} 2$ receptors in Alzheimer-type dementia. Neurobiol Aging 1986; 7: 3-8.

57. Middlemiss DN, Bowen DM, Palmer AM. Serotonin neurons and receptors in Alzheimer's disease. In: Briley M, Kato A, and Weber M, eds. New Concepts in Alzheimer's Disease. Pierre Fabre Monograph Series vol. 1. London: Macmillan Press, 1986: 89-102.

58. Procter AW, Middlemiss DN, Bowen DM. Selective loss of serotonin recognition sites in the parietal cortex in Alzheimer's disease. Int J Geriat Psychiat 1988; 3: 37-44.

59. Procter AW, Sterling JH, Stratmann GC. Loss of glycine-dependent radioligand binding to the $\mathrm{N}$-methyl-D-aspartate-phencyclidine receptor complex in patients with Alzheimer's disease. Neurosci Lett 1989; 101: 62-66.

60. Beal MF, Mazurek MF, Tran VT, et al. Reduced numbers of somatostatin receptors in the cerebral cortex in Alzheimer's disease. Science 1985; 224: 284-291.

61. Cross AJ, Crow TJ, Ferrier IN, et al. Striatal dopamine receptors in Alzheimer-type dementia. Neurosci Lett 1984; 52: 1-6.

62. Rinne JO, Sako E, Paljora L, et al. Brain dopamine D-2 receptors in senile dementia. J Neurol Trans 1986; 65: 51-62.

63. Palmer AM, Hudson PH, Lowe SL, et al. Extracellular concentrations of aspartate and glutamate in rat neostriatum following chemical stimulation of frontal cortex. Exp Brain Res 1989; 75 : 659-663.

64. Neary D, Snowden JS, Bowen DM, et al. Neuropsychological syndromes in presenile dementia due to cerebral atrophy. J Neurol Neurosurg Psychiat 1986; 49: 163-174.

65. Neary D, Snowden JS, Mann DMA, et al. Alzheimer's disease; a correlative study. J Neurol Neurosurg Psychiatry 1986; 49: 229237.

66. Bowen DM, Smith CB, White P, et al. Chemical pathology of the organic dementias: I Validity of biochemical measurements in human postmortem brain specimens. Brain 1977; 100: 397-426.

67. Korey SR, Scheinberg L, Terry R, et al. Studies in presenile dementia. Trans Am Neurol Assoc 1961; 86: 99-102. 
68. Smith CCT, Bowen DM, Sims NR, et al. Amino acid release from biopsy samples of temporal neocortex from patients with Alzheimer's disease. Brain Res 1983; 264: 138-141.

69. Spillane JA, White P, Goodhart MJ, et al. Selective vulnerability of neurons in organic dementia. Nature 1977; 266: 3558-3560.

70. Palmer AM, Francis PT, Benton JS, et al. Presynaptic serotonergic dysfunction in patients with Alzheimer's disease. J Neurochem 1987; 8-15.

71. Sims NR, Bowen DM, Allen ST, et al. Presynaptic cholinergic dysfunction in patients with dementia. J Neurochem 1983; 40: 503509.

72. Cotman CW, Geddes JW, Monahan DT, et al. Excitatory amino acid receptors in Alzheimer's disease. In: Davies P, Finch CE, eds. Molecular Neuropathology of Aging (Banbury report 27), Cold Spring Harbor Laboratory, 1987; 67-84.

73. Francis PT, Palmer AM, Sims NR, et al. Neurochemical studies of early-onset Alzheimer's disease: Possible influence on treatment. N Engl J Med 1985; 313: 7-11.

74. Cutler NR, Haxby JV, Duara R, et al. Clinical history, brain metabolism and neuropsychological function in Alzheimer's disease. Ann Neurol 1985; 18: 298-309.

75. Miller JD, de Leon MJ, Ferris SH, et al. Abnormal temporal lobe response in Alzheimer's disease during cognitive processing as measured by ["1C]-2-deoxy-D-glucose and PET. J Cereb Blood Flow Metab 1987; 7: 248-25I.

76. Pearson RCA, Esiri MM, Hiorns RW, et al. Anatomical correlates of the distribution of the pathological changes in the neocortex in Alzheimer's disease. Proc Natl Acad Sci USA 1985; 82: 45314534.

77. Ayer-LeLievre C, Olson L, Ebendal T, et al. Expression of the Bnerve growth factor gene in hippocampal neurons. Science 1988; 240: 1339-1341.

78. Dawbarn D, Allen SJ, Semenenko FM. Coexistence of choline acetyltransferase and nerve growth factor receptors in the rat basal forebrain. Neurosci Lett 1988; 94: 138-144.

79. Hyman BT, Van Hoesen GW, Damasio AR. Alzheimer's disease: glutamate depletion in the hippocampal perforant pathway zone. Ann Neurol 1987; 22: 37-40.

80. Bowen DM. Alzheimer's disease. In: Davison AN, Thompson RHS, eds. The Molecular Basis of Neuropathology. London: Edward Arnold, 1981: 649-665.

81. Pearson RCA, Powell JPS. The neuroanatomy of Alzheimer's disease. Rev Neurosci (in press).

82. Terry RD. Ultrastructural alterations in senile dementia. In: Katzman R, Terry RD, eds. Alzheimer's Disease: Senile
Dementia and Related Disorders. (Aging, Vol 7). New York, Raven Press, 1978; 375-382.

83. Saraiva AA, Borges MM, Madeira MD, et al. Mitochondrial abnormalities in cortical dendrites from patients with Alzheimer's disease. J Submicroscopic Cytol 1985; 17: 459-464.

84. Sims NR, Finegan JM, Blass JP, et al. Mitochondrial function in brain tissue in primary degenerative dementia. Brain Res 1987; 436: 30-38.

85. Bowen DM, Davison AN. Cathepsin A in human brain and spleen. Biochem J 1973; 131: 417-419.

86. Gottfries CG, Kjallquist A, Ponten U, et al. Cerebrospinal fluid $\mathrm{pH}$ and monoamine and glucolytic metabolites in Alzheimer's disease. Br J Psychiat 1974; 124: 280-287.

87. Talamo BR, Rudel R, Kosik KS, et al. Pathological changes in olfactory neurons in patients with Alzheimer's disease. Nature 1989; 337: 736-739

88. Lennox G, Lowe J, Byrne EJ, et al. Diffuse Lewy body disease. Lancet 1989; i: 323-324.

89. Mesulam MM, Geula C. Acetylcholinesterase - rich pyramidal neurons in the human neocortex and hippocampus: Absence at birth, development during the life span, and dissolution in Alzheimer's disease. Ann Neurol 1988; 24: 765-773.

90. Small DH, Simpson RJ. Acetylcholinesterase undergoes autolysis to generate trypsin-like activity. Neurosci Lett 1988; 89: 223228.

91. Jayson D, Esiri MM, Smith AD. Histochemical evidence for a change in distribution and character of acetylcholinesterase in Alzheimer's disease brain. Quart J Med (in press).

92. Gauthier S, Masson H, Gauthier R, et al. Tetrahydroaminoacridine and lecithin in Alzheimer's disease. In: Giacobini E, Becker R, eds. Current Research in Alzheimer Therapy. New York: Taylor and Francis 1988; 237-245.

93. Balazs R, Jorgensen OS, Hack N. N-Methyl-D-aspartate promotes the survival of cerebellar granule cells in culture. Neuroscience 1988; 27: 437-451.

94. Brewer GJ, Cotman CW. NMDA promotes branching, MK801 stimulates elongation of dentate granule neurons. Soc Neurosci Abst 1988; 14: 115.

95. Waters C. Cognitive enhancing agents: Current status in the treatment of Alzheimer's disease. Can J Neurol Sci 1988; 15: 249256.

96. Neary D, Snowden JS, Bowen DM, et al. Cerebral biopsy in the investigation of presenile dementia due to cerebral atrophy. $J$ Neurol Neurosurg Psychiatry 1986; 49: 157-162. 